\title{
Handbuch für die
}

deutsche Handelsmarine

auf das Jahr 1938

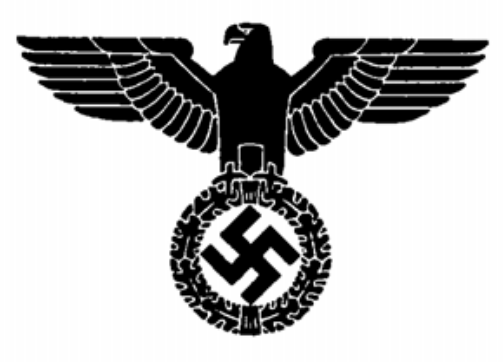

Herausgegeben vom

Reichsverkehrsministerium

Verlag von Walter de Gruyter \& Co.

Berlin 1938 
Archiv-Nr. 340438

Druck von Walter de Gruyter \& Co., Berlin W 35

Printed in Germany 